\title{
Effect of Zinc Application on Yield Attributes and Yield of Maize and Wheat in Maize-Wheat Cropping System
}

\author{
Dileep Kumar ${ }^{1 *}$, Shiva Dhar ${ }^{2}$, Sanjeev Kumar ${ }^{3}$, Dinesh Chand Meena ${ }^{4}$ and \\ Ram Bhawan Meena ${ }^{4}$ \\ ${ }^{1}$ ICAR-Indian Institute of Sugarcane Research, Lucknow, India \\ ${ }^{2}$ ICAR-Indian Agricultural Research Institute, New Delhi-110 012, India \\ ${ }^{3}$ ICAR-Nation Dairy Research Institute, Karnal, Haryana- 132 001, India \\ ${ }^{4}$ ICAR-Indian Institute of Soil and Water Conservation, Chhalesar Agra 282 006, India \\ *Corresponding author
}

\section{Keywords}

Zinc, Harvest index,

Yield, Maize-wheat cropping system

\section{Article Info}

Accepted:

14 December 2018

Available Online:

10 January 2019

\section{A B S T R A C T}

An experiment was conducted during 2009-10 and 2010-11 at research farm of division of Agronomy, IARI, New Delhi, to study the effect of various doses and methods of zinc application on maize and wheat. The treatment consisted of control, $12.5 \mathrm{~kg} \mathrm{ZnSO}_{4} \mathrm{ha}^{-1}$, $25 \mathrm{~kg} \mathrm{ZnSO}_{4} \mathrm{ha}^{-1}$ and foliar spray of $0.5 \% \mathrm{ZnSO}_{4}$ and two wheat Varieties 'DBW 17' and 'PBW 343'. The grain, stover and biological yield of maize were significantly influenced by application of zinc during first year and the maximum yields were recorded with the application of $25 \mathrm{~kg} \mathrm{ZnSO}_{4} \mathrm{ha}^{-1}$ during both the year. During first year application of $25 \mathrm{~kg}$ $\mathrm{ZnSO}_{4}, 12.5 \mathrm{ZnSO}_{4} \mathrm{ha}^{-1}$ and foliar spray of $0.5 \% \mathrm{ZnSO}_{4}$ increased grain yield by 22.81 , 18.63 and 8.36 percent respectively over control, while $4.10,2.41$ and $1.69 \%$ increase in grain yield was recorded during second year. In wheat, application of $25 \mathrm{~kg} \mathrm{ZnSO}_{4} \mathrm{ha}^{-1}$ significantly increased 1000 grain weight during both the years while during second year effective tiller $\mathrm{m}^{-2}$, grain spike ${ }^{-1}$ and grain diameter; as compared to the remaining treatment. This treatment increased the number of effective tillers by 6,10 and 11 percent over the application of $12.5 \mathrm{~kg} \mathrm{ZnSO}_{4} \mathrm{ha}^{-1}$, foliar spray and control, respectively, during second year. Direct application of zinc to wheat varieties i.e. 'DBW 17' and 'PBW 343' showed significant variation in grain, straw and biological yield and harvest index during both the years. The yield advantage of $0.35,0.26$ and 0.28 and $0.43,0.13$ and $0.29 \mathrm{t} \mathrm{ha}^{-1}$ was recorded with the application of $25 \mathrm{~kg} \mathrm{ZnSO}_{4} \mathrm{ha}^{-1}$ over control, $12.5 \mathrm{~kg} \mathrm{ZnSO}_{4} \mathrm{ha}^{-1}$ and foliar spray, respectively. Highest straw and total biological yields were obtained with the application of $25 \mathrm{~kg} \mathrm{ZnSO}_{4} \mathrm{ha}^{-1}$.

\section{Introduction}

Maize and wheat is the main source of world's food energy and also contains significant amounts of proteins, minerals and vitamins which are highly essential nutrients for human health. Wheat is a major important crop along with other cereals supplies the bulk of calories and nutrients in the diets of a large proportion of population (Water et al., 2009; Chatzav et 
al., 2010). Globally, India ranks as second largest wheat producing nation and contributes near about $11.9 \%$ to the world wheat production from about $12 \%$ area of world (Singh et al., 2010). Study conducted across the country and shows stagnating or declining rice and wheat yields in the Indo-Gangetic Plains, which have likely been related to soil fertility and frequent appearance of micronutrient deficiency especially, zinc (Benbi et al., 2012).

Maize is considered a promising option for diversification of agriculture in upland areas of country and now it is recognised as the third most important food grain crop in the nation. The maize area has slowly increased over the past few years to about 6.2 million ha (3.4\% of the gross cropped area) in 1999/2000 (Joshi et al., 2005). It also predicted that area under this crop would grow further to fulfil future food, feed, fodder and other requirements, especially in view of the booming livestock and poultry farming sectors in the country. It not only in our country, but also in our neighbouring country China wheatmaize (Zea mays L.) rotation is a predominant cropping system, covering up to $60 \%$ of arable land (Liang et al., 2012). Since opportunities are limited for further expansion of maize area, therefore future requirements of maize grain may be achieved through the intensification of current maize production system. It is quite visible now days that micro nutrient getting deficient and the capacity of soils to supply $\mathrm{Zn}$ for optimal crop growth vary widely too. Soils deficient in their ability to supply $\mathrm{Zn}$ to crops are alarmingly widespread across the world, and it occurs most frequently in arid and semi-arid regions of the including Pakistan, India, Turkey, China, etc. Zn deficiency has been reported in a number of crop species like rice, maize, cotton, etc. (Behera et al., 2011; Ram et al., 2010; Khan and Joergensen, 2010; Cakmak et al., 1999).
Deficiency of zinc affect the yield and quality of crops over large areas of the world's cultivable land (Genc et al., 2009; Coventry et al., 2011; Misra et al., 2005). Micronutrients play an active role in the plant metabolic processes beginning from cell development to respiration, photosynthesis, chlorophyll formation, enzyme activity, nitrogen fixation etc.

Micronutrient requirements of the maize and wheat crops are relatively low and ranges between their deficiencies and toxicities in plants and soils are quite narrow. Unlike the malnutrition that is due to lack of food and which has drawn the attention globally, the hidden hunger of micronutrient deficiencies affect severely to even more people and damage is long lasting on human kind and their societies (Teng et al., 2012; Patel et al., 2011; Cakmak 2002; Simic et al., 2012). The main reason behind the wide-spread emergence of Zn deficiency in country; after the Green Revolution high nutrient exhaustive crop rotations followed such as rice-wheat along with imbalanced fertilization and high doses of nitrogen, nutrient uptake by both grain and straw from the field and very less or negligible application of organic manures (Suri et al., 2011). Zinc deficiencies can be corrected in most cases by applying a granular $\mathrm{Zn}$ fertilizer or applying it with the starter macronutrient (NPK) fertilizer either as a coating or incorporated into the macronutrient granule and zinc sulfate $\left(\mathrm{ZnSO}_{4}\right)$ has been the $\mathrm{Zn}$ source of choice.

\section{Materials and Methods}

The field experiments were conducted during kharif and rabi seasons of 2009-10 and 201011 at the Research Farm of Division of Agronomy, Indian Agricultural Research Institute, New Delhi, situated at $28.4^{\circ} \mathrm{N}$ latitude and $77.1^{\circ} \mathrm{E}$ longitude and at an altitude of 228.6 meters above mean sea level. The 
climate of site is semi-arid to sub-tropical with extreme cold and hot situations. Average annual rainfall of the site is about $652 \mathrm{~mm}, 84$ $\%$ of which is received during south-west monsoon. The mechanical analysis of soil was done using hydrometer method (Bouyoucos, 1962) and the soil was sandy loam in soil texture. The soil of experimental site was normal in reaction, $\mathrm{pH} 7.8$ (1:2.5 soil: water ratio) (Piper, 1950), medium in organic $\mathrm{C}$, $0.38 \%$ (Walkey and Black, 1934), low in alkaline permanganate oxidizable nitrogen,163.2 kg N/ha (Subbiah and Asija, 1956), medium in available $P, 12.2 \mathrm{~kg} \mathrm{ha}^{-1}$ (Olsen et al., 1954) and $1 \mathrm{~N}$ ammonium acetate exchangeable $\mathrm{K}, 239 \mathrm{~kg} \mathrm{ha}^{-1}$ (Jackson, 1973) and DTPA extractable Zn,0.72 ppm (Lindsay and Norvell, 1978).

The experiment was conducted in split plot design with three replications in a fixed lay out. The main- plot treatments consisted of four levels of zinc sulphate (heptahydrate) $\mathrm{ZnSO}_{4} .7 \mathrm{H}_{2} \mathrm{O}$ and two method of zinc application to maize viz. control, $12.5 \mathrm{~kg}$ $\mathrm{ZnSO}_{4} \mathrm{ha}^{-1}, 25 \mathrm{~kg} \mathrm{ZnSO}_{4} \mathrm{ha}^{-1}$ and foliar spray of $0.5 \% \mathrm{ZnSO}_{4}$ at knee height stage and one week later after previous spray, Whereas the sub-plot treatments applied to wheat were four $\mathrm{Zn}$ levels viz. control, $12.5 \mathrm{~kg} \mathrm{ZnSO}_{4} \mathrm{ha}^{-1}, 25$ $\mathrm{kg} \mathrm{ZnSO} \mathrm{ha}^{-1}$, and two foliar spray of $0.5 \%$ $\mathrm{ZnSO}_{4}$ at anthesis and one week after previous spray on two wheat varieties 'DBW 17' and 'PBW 343'. The maize variety 'PEHM 2' was sown with row spacing of $60 \mathrm{~cm}$ apart during kharif and wheat varieties 'PBW 343' and 'DBW 17' were sown in lines at $22 \mathrm{~cm}$ apart during rabi season.

\section{Observations}

Yield attributes, viz. number of grain/cob, number of grain row/cob, 1000-grain weight, girth of cob, and length of cob for maize whereas in wheat number of spikes $/ \mathrm{m}^{2}$, grains/spike, length of spike,1000-grain weight were recorded. The biological yield, grain yield and stover yields were recorded. The harvest index was calculated as the ratio of economic produce (grain yield) and the biological yield (grain + stover or straw).

\section{Statistical analysis}

The data recorded for different parameters were analysed with the help of analysis of variance (ANOVA) technique for a split plot design using MSTAT-C software. Source of variation and corresponding degrees of freedom used in the ANOVA are given in Annexure-I. The results are presented at 5\% level of significance $(\mathrm{P}=0.05)$.

\section{Results and Discussion}

\section{Yields attributes and yield of maize}

In present study, yield attributes viz. number of grain $\mathrm{cob}^{-1}$, 1000-grain weight, number of grain row $\mathrm{cob}^{-1}$, cob length and cob girth of maize and grain weight spike ${ }^{-1}$ of wheat were not affected significantly with the application of zinc (Table 1 and 2). However, these parameters were slightly better with the application of $25 \mathrm{~kg} \mathrm{ZnSO} 4 \mathrm{ha}^{-1}$ to both the crops during the course of study. This might be due to the better role of $\mathrm{Zn}$ during reproductive phase of crop growth. The application of $25 \mathrm{~kg} \mathrm{ZnSO} 4 \mathrm{ha}^{-1}$ increases the yield of wheat as compared to control.

However (Singh et al., 2009) observed that application of $15 \mathrm{~kg} \mathrm{ZnSO} \mathrm{Zha}^{-1}$ found more responsive to 'PBW 343'. Zinc application significantly increases yield of maize (Shukla and Prasad 1974; Sajedi et al., 2010).

The maize grain, stover and biological yields were significantly influenced by zinc application during first year (Table 3) and maximum yields were recorded with the application of $25 \mathrm{~kg} \mathrm{ZnSO}_{4} \mathrm{ha}^{-1}$ during both 
the year. During first year grain yield due to application of $25 \mathrm{~kg} \mathrm{ZnSO}_{4} \mathrm{ha}^{-1}$ was higher by 22.81, 18.63 and 8.36 percent and 4.10, 2.41 and 1.69 percent was higher over control, foliar spray of $0.5 \% \mathrm{ZnSO}_{4}$ and $12.5 \mathrm{~kg}$ $\mathrm{ZnSO}_{4} \mathrm{ha}^{-1}$ during second year, respectively. This might be due to more yield attributing character recorded with the application of 25 $\mathrm{kg} \mathrm{ZnSO}_{4} \mathrm{ha}^{-1}$ and more source translocate towards sink. Sachin et al., (2011) recorded that significantly higher grain yield of maize with increasing dose up to $50 \mathrm{~kg} \mathrm{ZnSO}_{4} \mathrm{ha}^{-1}$. Application of 1 to $2 \mathrm{~kg} \mathrm{Zn} \mathrm{ha}{ }^{-1}$ to maize increases the grain yield in range of 814-1747 $\mathrm{kg} \mathrm{ha}^{-1}$ (Osiname et al., 1973). Comparing different level of zinc application to crop showed that increase in 100 seed weight and seed yield, obtained by zinc spraying (Salehin and Rahman, 2012). The overall performance of yield attributes was better during second year in comparison to first year because the most important weather parameter i.e. rainfall distribution and quantity was more during second year which helped in better crop growth that ultimately reflected in the yield of crop. The dry matter production of maize increased with the increasing zinc levels using three sources of zinc (Goos et al., 2000).

\section{Yields attributes of wheat}

The yield attributing character of wheat such as 1000 grain weight during first year and grain weight spike $^{-1}$ were higher with the application of $25 \mathrm{~kg} \mathrm{ZnSO} \mathrm{Zha}^{-1}$ to preceding maize crop. This might be due to uptake of residual zinc applied to previous maize crop and not fully utilized due to less moisture stress during crop growing season. In wheat varieties the application of $25 \mathrm{~kg} \mathrm{ZnSO}_{4} \mathrm{ha}^{-1}$ gave significantly higher effective tiller $\mathrm{m}^{-2}$, grain spike ${ }^{-1}$ and grain diameter during second year; 1000 grain weight during both the year than the control, 12.5 and foliar spray (Table 4). The effective tillers were increased $b$ due to application of $25 \mathrm{~kg} \mathrm{ZnSO}_{4} \mathrm{ha}^{-1}$ by 6,10 and 11 percent over $12.5 \mathrm{~kg} \mathrm{ZnSO}_{4} \mathrm{ha}^{-1}$, foliar spray of $0.5 \quad \% \quad \mathrm{ZnSO}_{4}$ and control, respectively during second year. However, 1000 grain weight was 2, 3 and 4 percent higher than $12.5 \mathrm{~kg} \mathrm{ZnSO}_{4} \mathrm{ha}^{-1}$, foliar spray of $0.5 \% \mathrm{ZnSO}_{4}$ and control, respectively during second year. The effective tiller In variety 'PBW 343' were found higher with the application $25 \mathrm{~kg} \mathrm{ZnSO}_{4} \mathrm{ha}^{-1}$ than control, $12.5 \mathrm{~kg} \mathrm{ZnSO}_{4} \mathrm{ha}^{-1}$ and foliar spray of $0.5 \%$ $\mathrm{ZnSO}_{4}$ by 15, 2 and 7 percent and 1000 grain by 5,2 and 4 during first year, respectively.

The increase in these parameters might be due to involvement of zinc in various enzymatic processes which helps in catalyzing reaction for growth finally leading to development of more yield attributing character. The results were in close conformity with Jakhar et al., (2006).Response to zinc of both varieties regarding effective tiller $\mathrm{m}^{-2}, 1000$ grain weight grains spike ${ }^{-1}$, and grain diameter was better during second year, because during ear head initiation period light rainfall occurred, which helped in providing favourable growing conditions and better mobilisation of zinc. Hasanzadeh et al., (2012) reported that due to water shortage leads to reduction in concentration of zinc in plant. Another most important factor that zinc play crucial role especially at blooming stage which is required for good grain setting in spike. The variety 'PBW 343'produced bolder grain during both the year than 'DBW 17' this may be due better response of zinc application and inherent character of variety.

\section{Grain, straw and biological yield of wheat}

The grain, straw and biological yields recorded marginally higher with the application of $25 \mathrm{~kg} \mathrm{ZnSO} 4 \mathrm{ha}^{-1}$ to previous maize but it did not show significant variations. All these parameters were recorded more during first year in comparison to second year due to better growing conditions. 
Table.1 Effect of zinc application on yield attributing character of maize

\begin{tabular}{|c|c|c|c|c|c|c|}
\hline \multirow[t]{2}{*}{$\begin{array}{l}\text { Treatment } \\
\text { application of } \mathrm{ZnSO}_{4}\end{array}$} & \multicolumn{2}{|c|}{$\begin{array}{c}\text { Weight of cob plant } \\
\text { (g) }\end{array}$} & \multicolumn{2}{|c|}{ Grains cob $^{-1}$} & \multicolumn{2}{|c|}{ Grain rows cob $^{-1}$} \\
\hline & 2009 & 2010 & 2009 & 2010 & 2009 & 2010 \\
\hline Control & 91.5 & 99.0 & 371 & 385 & 13 & 13 \\
\hline $12.5 \mathrm{~kg} \mathrm{ha}^{-1}$ & 96.7 & 102.0 & 375 & 392 & 14 & 15 \\
\hline $25 \mathrm{~kg} \mathrm{ha}^{-1}$ & 97.8 & 103.6 & 384 & 394 & 14 & 15 \\
\hline Foliar spray of $(0.5 \%)^{*}$ & 94.3 & 99.7 & 377 & 385 & 14 & 14 \\
\hline SEm \pm & 1.7 & 4.5 & 9.5 & 8.7 & 0.9 & 0.4 \\
\hline $\mathrm{CD}(\mathrm{P}=0.05)$ & NS & NS & NS & NS & NS & NS \\
\hline
\end{tabular}

* One spray at the four leaf stage and one week after first spray

Table.2 Effect of zinc application on yield attributing character of maize

\begin{tabular}{|c|c|c|c|c|c|c|c|c|}
\hline \multirow[t]{2}{*}{$\begin{array}{l}\text { Treatment } \\
\text { application of } \mathrm{ZnSO}_{4}\end{array}$} & \multicolumn{2}{|c|}{$\begin{array}{c}\text { Length of cob } \\
\text { (cm) }\end{array}$} & \multicolumn{2}{|c|}{ Test weight (g) } & \multicolumn{2}{|c|}{ Cob girth $(\mathbf{c m})$} & \multicolumn{2}{|c|}{$\begin{array}{c}\text { Shelling } \\
(\%)\end{array}$} \\
\hline & 2009 & 2010 & 2009 & 2010 & 2009 & 2010 & 2009 & 2010 \\
\hline Control & 12.5 & 14.1 & 223.2 & 230.1 & 12.5 & 13.8 & 77.5 & 80.5 \\
\hline $12.5 \mathrm{~kg} \mathrm{ha}^{-1}$ & 13.0 & 14.5 & 228.5 & 237.3 & 13.7 & 14.3 & 80.9 & 82.0 \\
\hline $25 \mathrm{~kg} \mathrm{ha}^{-1}$ & 13.1 & 15.1 & 229.9 & 243.8 & 14.6 & 15.9 & 82.7 & 83.9 \\
\hline Foliar spray $(0.5 \%) *$ & 12.9 & 14.3 & 227.2 & 233.8 & 13.3 & 14.3 & 79.3 & 80.7 \\
\hline SEm \pm & 0.61 & 0.4 & 1.3 & 4.2 & 0.61 & 0.6 & 1.8 & 2.5 \\
\hline $\mathrm{CD}(\mathrm{P}=\mathbf{0 . 0 5})$ & NS & NS & NS & NS & NS & NS & NS & NS \\
\hline
\end{tabular}

* One spray at the four leaf stage and one week after first spray

Table.3 Effect of zinc application on yield and harvest index of maize

\begin{tabular}{|c|c|c|c|c|c|c|c|c|}
\hline \multirow[t]{2}{*}{$\begin{array}{l}\text { Treatment } \\
\text { application of } \mathrm{ZnSO}_{4}\end{array}$} & \multicolumn{2}{|c|}{$\begin{array}{c}\text { Grain yield } \\
\left(t \text { ha }^{-1}\right)\end{array}$} & \multicolumn{2}{|c|}{$\begin{array}{l}\text { Stover yield } \\
\left(\mathrm{t} \mathrm{ha}^{-1}\right)\end{array}$} & \multicolumn{2}{|c|}{$\begin{array}{c}\text { Biological yield } \\
\left(\mathrm{t} \mathrm{ha}^{-1}\right)\end{array}$} & \multicolumn{2}{|c|}{$\begin{array}{c}\text { Harvest index } \\
(\%)\end{array}$} \\
\hline & 2009 & 2010 & 2009 & 2010 & 2009 & 2010 & 2009 & 2010 \\
\hline Control & 2.03 & 3.97 & 4.4 & 8.32 & 6.43 & 12.29 & 31.7 & 32.3 \\
\hline $12.5 \mathrm{~kg} \mathrm{ha}^{-1}$ & 2.41 & 4.07 & 5.54 & 8.45 & 7.95 & 12.52 & 30.3 & 32.5 \\
\hline $25 \mathrm{~kg} \mathrm{ha}^{-1}$ & 2.63 & 4.14 & 6.44 & 8.55 & 9.07 & 12.69 & 29.0 & 32.5 \\
\hline Foliar spray $(0.5 \%)^{*}$ & 2.14 & 4.04 & 5.38 & 8.37 & 7.52 & 12.41 & 28.5 & 32.4 \\
\hline SEm \pm & 0.11 & 0.37 & 0.11 & 0.87 & 0.34 & 0.35 & 1.5 & 2.1 \\
\hline $\mathrm{CD}(\mathrm{P}=0.05)$ & 0.38 & NS & 0.38 & NS & 1.18 & NS & NS & NS \\
\hline
\end{tabular}

* One spray at the four leaf stage and one week after first spray 
Table.4 Effect of zinc application on yield attributing characters of wheat

\begin{tabular}{|c|c|c|c|c|c|c|c|c|c|c|}
\hline \multirow{2}{*}{$\begin{array}{c}\text { Treatment } \\
\text { Application of } \mathrm{ZnSO}_{4}\end{array}$} & \multicolumn{2}{|c|}{$\begin{array}{c}\text { Effective tillers } \\
\left(\mathbf{m}^{-2}\right)\end{array}$} & \multicolumn{2}{|c|}{$\begin{array}{l}\text { Grain weight } \\
\text { spike }^{-1}(\mathrm{~g})\end{array}$} & \multicolumn{2}{|c|}{$\begin{array}{l}1000 \text { grain } \\
\text { weight (g) }\end{array}$} & \multicolumn{2}{|c|}{ Grain spike $^{-1}$} & \multicolumn{2}{|c|}{$\begin{array}{c}\text { Grain } \\
\text { diameter }(\mathbf{m m})\end{array}$} \\
\hline & $\begin{array}{c}2009- \\
10\end{array}$ & 2010-11 & $\begin{array}{c}2009- \\
10\end{array}$ & $\begin{array}{c}2010- \\
11\end{array}$ & $\begin{array}{c}2009- \\
10\end{array}$ & $\begin{array}{c}2010 \\
-11\end{array}$ & $\begin{array}{c}2009 \\
-10\end{array}$ & $\begin{array}{c}2010 \\
-11\end{array}$ & $\begin{array}{c}2009- \\
10\end{array}$ & $\begin{array}{c}2010- \\
11\end{array}$ \\
\hline \multicolumn{11}{|l|}{ Maize } \\
\hline Control & 299 & 335 & 2.03 & 1.99 & 35.1 & 36.5 & 44 & 52 & 2.03 & 2.80 \\
\hline $12.5 \mathrm{~kg} \mathrm{ha}^{-1}$ & 304 & 356 & 2.04 & 2.09 & 35.5 & 38.9 & 45 & 54 & 2.04 & 2.79 \\
\hline $25 \mathrm{~kg} \mathrm{ha}^{-1}$ & 306 & 354 & 2.19 & 2.11 & 37.2 & 39.3 & 45 & 55 & 2.19 & 2.86 \\
\hline $\begin{array}{l}\text { Foliar spray } \\
(0.5 \%)^{*}\end{array}$ & 300 & 351 & 2.02 & 2.09 & 35.2 & 37.0 & 44 & 53 & 2.02 & 2.88 \\
\hline SEm \pm & 4.23 & 5.93 & 0.08 & 0.02 & 0.37 & 0.9 & 0.43 & 0.50 & 0.08 & 0.03 \\
\hline $\mathrm{CD}(\mathrm{P}=0.05)$ & NS & NS & NS & 0.08 & 1.28 & NS & NS & 1.75 & NS & NS \\
\hline \multicolumn{11}{|l|}{ Wheat 'DBW 17' } \\
\hline Control & 302 & 332 & 2.01 & 2.00 & 35.5 & 35.7 & 43 & 51 & 2.01 & 2.76 \\
\hline $12.5 \mathrm{~kg} \mathrm{ha}^{-1}$ & 305 & 350 & 2.20 & 2.08 & 35.3 & 36.6 & 45 & 53 & 2.20 & 2.78 \\
\hline $25 \mathrm{~kg} \mathrm{ha}^{-1}$ & 307 & 372 & 2.22 & 2.15 & 36.9 & 37.2 & 46 & 54 & 2.22 & 2.79 \\
\hline $\begin{array}{l}\text { Foliar spray } \\
(0.5 \%)^{*}\end{array}$ & 303 & 336 & 2.04 & 2.06 & 35.5 & 36.1 & 45 & 53 & 2.04 & 2.81 \\
\hline \multicolumn{11}{|l|}{ 'PBW 343' } \\
\hline Control & 295 & 317 & 1.89 & 2.03 & 34.9 & 39.3 & 43 & 53 & 1.89 & 2.88 \\
\hline $12.5 \mathrm{~kg} \mathrm{ha}^{-1}$ & 302 & 366 & 2.05 & 2.11 & 35.9 & 39.4 & 45 & 55 & 2.05 & 2.88 \\
\hline $25 \mathrm{~kg} \mathrm{ha}^{-1}$ & 306 & 373 & 2.11 & 2.12 & 36.8 & 39.7 & 44 & 57 & 2.11 & 2.87 \\
\hline $\begin{array}{l}\text { Foliar spray } \\
(\mathbf{0 . 5 \%})^{*}\end{array}$ & 299 & 346 & 2.03 & 1.99 & 35.2 & 39.7 & 43 & 53 & 2.03 & 2.90 \\
\hline SEm \pm & 4.86 & 10.6 & 0.08 & 0.06 & 0.49 & 0.6 & 0.7 & 0.7 & 0.08 & 0.02 \\
\hline $\mathrm{CD}(\mathrm{P}=0.05)$ & NS & 30.1 & NS & NS & 1.41 & 1.7 & NS & 2.2 & NS & 0.06 \\
\hline
\end{tabular}

*Two foliar spray one at anthesis and another one week later 
Table.5 Effect of zinc application on yield and harvest index of wheat

\begin{tabular}{|c|c|c|c|c|c|c|c|c|}
\hline \multirow[t]{2}{*}{$\begin{array}{l}\text { Treatment } \\
\text { application of } \mathrm{ZnSO}_{4}\end{array}$} & \multicolumn{2}{|c|}{$\begin{array}{c}\text { Grain yield } \\
\left(\mathrm{t} \mathrm{ha}^{-1}\right)\end{array}$} & \multicolumn{2}{|c|}{$\begin{array}{c}\text { Straw yield } \\
\left(\mathrm{t} \mathrm{ha}^{-1}\right)\end{array}$} & \multicolumn{2}{|c|}{$\begin{array}{c}\text { Biological yield } \\
\left(\mathrm{t} \mathrm{ha}^{-1}\right)\end{array}$} & \multicolumn{2}{|c|}{ Harvest index } \\
\hline & 2009-10 & $2010-11$ & $2009-10$ & $\begin{array}{c}2010- \\
11\end{array}$ & $2009-10$ & $\begin{array}{c}2010- \\
11\end{array}$ & $2009-10$ & 2010-11 \\
\hline \multicolumn{9}{|l|}{ Maize) } \\
\hline Control & 4.14 & 4.48 & 6.76 & 6.93 & 10.89 & 11.41 & 38.1 & 39.5 \\
\hline $12.5 \mathrm{~kg} \mathrm{ha}^{-1}$ & 4.21 & 4.84 & 6.81 & 7.38 & 11.02 & 12.22 & 38.6 & 39.8 \\
\hline $25 \mathrm{~kg} \mathrm{ha}^{-1}$ & 4.28 & 4.96 & 6.98 & 7.66 & 11.25 & 12.62 & 38.1 & 39.5 \\
\hline $\begin{array}{l}\text { Foliar spray }(0.5 \\
\%)^{*}\end{array}$ & 4.18 & 4.61 & 6.79 & 7.19 & 10.97 & 11.80 & 38.1 & 39.1 \\
\hline SEm \pm & 0.06 & 0.11 & 0.09 & 0.23 & 0.08 & 0.24 & 0.5 & 0.98 \\
\hline $\mathrm{CD}(\mathbf{P}=0.05)$ & NS & NS & NS & NS & NS & NS & NS & NS \\
\hline \multicolumn{9}{|l|}{ Wheat 'DBW 17' } \\
\hline Control & 4.07 & 4.39 & 6.74 & 6.79 & 10.81 & 11.18 & 37.7 & 39.6 \\
\hline $12.5 \mathrm{~kg} \mathrm{ha}^{-1}$ & 4.23 & 4.79 & 6.92 & 7.66 & 11.15 & 12.45 & 38.1 & 38.7 \\
\hline $25 \mathrm{~kg} \mathrm{ha}^{-1}$ & 4.43 & 4.85 & 7.13 & 8.41 & 11.56 & 13.26 & 38.5 & 36.5 \\
\hline $\begin{array}{l}\text { Foliar spray }(0.5 \\
\%)^{*}\end{array}$ & 4.17 & 4.54 & 6.81 & 7.20 & 10.98 & 11.73 & 38.0 & 38.6 \\
\hline \multicolumn{9}{|l|}{ 'PBW 343' } \\
\hline Control & 4.05 & 4.59 & 6.53 & 6.32 & 10.58 & 10.91 & 38.3 & 42.2 \\
\hline $12.5 \mathrm{~kg} \mathrm{ha}^{-1}$ & 4.14 & 4.89 & 6.82 & 7.23 & 10.96 & 12.12 & 37.8 & 40.4 \\
\hline $25 \mathrm{~kg} \mathrm{ha}^{-1}$ & 4.40 & 5.02 & 7.06 & 7.71 & 11.46 & 12.73 & 38.5 & 39.4 \\
\hline $\begin{array}{l}\text { Foliar spray }(0.5 \\
\%)^{*}\end{array}$ & 4.12 & 4.73 & 6.66 & 7.01 & 10.77 & 11.73 & 38.2 & 40.3 \\
\hline SEm \pm & 0.07 & 0.13 & 0.15 & 0.20 & 0.17 & 0.24 & 0.6 & 0.9 \\
\hline $\mathrm{CD}(\mathrm{P}=0.05)$ & 0.20 & 0.38 & NS & 0.57 & 0.47 & 0.67 & NS & 2.7 \\
\hline
\end{tabular}

*Two foliar spray one at anthesis and another one week later

During second year application of $25 \mathrm{~kg}$ $\mathrm{ZnSO}_{4}$ ha $^{-1}$ grain yield was higher by eight, 13 and 14 percent than the $12.5 \mathrm{~kg} \mathrm{ZnSO}_{4}$ $\mathrm{ha}^{-1}$, foliar and control treatment of first year, respectively. The grain yield recorded with the application of $25 \mathrm{~kg} \mathrm{ZnSO} 4 \mathrm{ha}^{-1}$ was higher by $0.36,0.20$ and $0.26 \mathrm{t} \mathrm{ha}^{-1}$ during first year while $0.46,0.06$ and $0.31 \mathrm{t} \mathrm{ha}^{-1}$ during second year than control, $12.5 \mathrm{~kg}$ $\mathrm{ZnSO}_{4} \mathrm{ha}^{-}$and foliar spray of $0.5 \% \mathrm{ZnSO}_{4}$, respectively (Table 5). The yield advantage with the application of $25 \mathrm{~kg} \mathrm{ZnSO}_{4} \mathrm{ha}^{-1}$ was $0.35,0.26$ and 0.28 during first year and 0.43 , 0.13 and $0.29 \mathrm{t} \mathrm{ha}^{-1}$ during second year as compared to control, $12.5 \mathrm{~kg} \mathrm{ZnSO}_{4} \mathrm{ha}^{-1}$ and foliar spray of $0.5 \% \mathrm{ZnSO}_{4}$, respectively in variety 'PBW 343. Highest straw yield 7.13 in first year and $8.41 \mathrm{t} \mathrm{ha}^{-1}$ second year in variety was obtained with the application of $25 \mathrm{~kg}$ $\mathrm{ZnSO}_{4} \mathrm{ha}^{-1}$. While in variety 'PBW 343' 
straw yield was 7.06 in first year and $7.71 \mathrm{t}$ $\mathrm{ha}^{-1}$ during second year. The total biological yield follows the similar trends as it depends upon the output of both grain and straw yield. This increase in yield might be due to better growth and yield attributing character with zinc fertilization. The grain, straw and biological yield were higher in variety 'PBW 343' than 'DBW 17' due to its more responsiveness to zinc application which was reflected in the form of superior yield attributes. The harvest index recorded maximum with $25 \mathrm{~kg} \mathrm{ZnSO} 4 \mathrm{ha}^{-1}$ during first year and with control during second year in variety 'DBW 17'. This effect might be due to relatively more straw yield during first year with the application of $25 \mathrm{~kg} \mathrm{ZnSO}_{4} \mathrm{ha}^{-1}$ while less grain yield in control during second year. Similar trend was also observed in variety 'PBW 343'. Hossain et al., (2008) reported that the grain yield increases significantly as $7.4,10.1$ and $10.6 \mathrm{t} \mathrm{ha}^{-1}$ with increasing $\mathrm{Zn}$ rates from 0,2 and $4 \mathrm{~kg} \mathrm{ha}^{-1}$, respectively. Likewise the straw yield due to 2 and $4 \mathrm{~kg} \mathrm{Zn} \mathrm{ha}^{-1}$ were found statistically similar particularly for the second and third year, and the yields were significantly different as recorded on the first year trial. Singh 2011 reported that zinc application at the rate of $5-10 \mathrm{~kg} \mathrm{ha}^{-1}$ increased the grain yield response by $0.2-2.6 \mathrm{t} \mathrm{ha}^{-1}$ in various prominent cropping systems in India including maize-wheat or rice-pulse cropping systems. Talliee and Abedi (1999) reported that the increase in grain yield of wheat was significantly more $\left(262 \mathrm{~kg} \mathrm{ha}^{-1}\right)$ with the application of $10 \mathrm{~kg} \mathrm{ha}^{-1} \mathrm{Zn}$ than control treatment.

In contrary to the findings, Verma and Minhas (1987) revealed that zinc application did not increase the grain and straw yield of wheat and maize when applied alone but increases significantly when applied in combination with phosphorus. Grant and Bailey (1998) reported that zinc application did not influence grain yield of durum wheat. Gul et al., (2011) found that foliar spray of $0.5 \%$ zinc has significant effect on number of grain (52) spike ${ }^{-1}, 1000$ grain weight (46 g), grain yield $\left(295 \mathrm{~kg} \mathrm{ha}^{-1}\right)$, straw yield $(6074 \mathrm{~kg}$ $\mathrm{ha}^{-1}$ ) and biological yield (8999 $\left.\mathrm{kg} \mathrm{ha}^{-1}\right)$.

Application of $12.5 \mathrm{~kg} \mathrm{ZnSO}_{4} \mathrm{ha}^{-1}$ to maize and wheat in system is equally effective as 25 $\mathrm{kg} \mathrm{ZnSO} 4 \mathrm{ha}^{-1}$ to the yield attributes and yield of both crops. But the maximum yield either in case of maize or in wheat crop obtained with application of highest dose of zinc. Both the crop responded significantly with the application of zinc levels as compared to control.

\section{References}

Behera S.K., Singh M.V., Singh K.N. and Todwal, S.: Distribution variability of total and extractable zinc in cultivated acid soils of India and their relationship with some selected soil properties Geoderma, 162: 242-250 (2011).

Benbi D. K., BrarKiranvir, Toor A. S., Singh Pritpal and Singh Hargopal: Soil carbon pools under poplar-based agroforestry, rice-wheat, and maize-wheat cropping systems in semi-arid India Nutrient Cycling in Agroecosystems, 92:107-118 (2012)

Bouyoucos, G.J.: Hydrometer method for making particle size analysis of soils Agronomy J., 54: 464 (1962).

Cakmak I., Kalayci M., Ekiz H., Braun H.J., Kilinc Y. and Yilmaz A.: Zinc deficiency as a practical problem in plant and human nutrition in Turkey: A NATO-science for stability project Field Crop Res., 60:175-188 (1999).

Cakmak, Ismail: Plant nutrition research: Priorities to meet human needs for food in sustainable ways Plant and Soil, 247: 3-24 (2002).

Chatzav Merav, Peleg Zvi, Ozturk Levent, 
Yazici Atilla, Fahima Tzion, Cakmak Ismail and Saranga Yehoshua: Genetic diversity for grain nutrients in wild emmer wheat: potential for wheat improvement Annals of Botany105: 1211-1220 (2010).

Coventry D.R., Poswal R.S., Yadav A., Gupta, R.K., Gill S.C., Chhokar R.S., Kumar V., Sharma R.K., Kumar A., Mehta A., Kleemann S.G.L and Cummins J.A.: Effect of tillage and nutrient management on wheat productivity and quality in Haryana, India Field Crops Res. 123: 234-240 (2011).

Genc Y., Verbyla A. P., Torun A. A., Cakmak I., Willsmore K., Wallwork H. and McDonald G. K.: Quantitative trait loci analysis of zinc efficiency and grain zinc concentration in wheat using whole genome average interval mapping Plant Soil 314:49-66 DOI 10.1007/s11104008-9704-3(2009).

Goos, R. Jay, Johnson Brian E. and Thiollet Marie: A comparison of the availability of three zinc sources to maize (Zea mays L.) under greenhouse conditions Bio.Fert.and Soils31:343-347 (2000).

Grant C. A. and Bailey L. D.: Nitrogen, phosphorus and zinc management effects on grain yield and cadmium concentration in two cultivars of durum wheat Canadian Journal of Plant Sci.78: 63-70 (1998).

Gul, Hasina, Said Ahmad, SaeedBeena, Mohammad Fida and Ahmad, Ijaz: Effect of foliar application of nitrogen, potassium and zinc on wheat growth. $J$. Agril. Bio. Sci., 6(4): 56-58 (2011).

Hasanzadeh, Elaheh, Sepanlou Mehdi Ghajar and Bahmanyar, Ali, Mohammad: Effects of potassium and manure fertilizers on concentration of micro elements in leaf and grain of wheat under water stress. European J. Exp. Bio., 2 (3): 520-524 (2012).
Hossain M. A., Jahiruddin M. and Khatun F.: Response of maize varieties to zinc fertilization Bangladesh J. Agric. Res., 36(3): 437-447 (2011).

Jackson, M.L.: Soil Chemical Analysis Prentice Hall of India Pvt. Ltd., New Delhi (1973).

Jakhar S R, Singh M and Balap, C. M.: Effect of farmyard manure, phosphorus zinc levels on growth, yield, quality and economics of pearl millet (Pennisetum glaucum) Indian J. Agric. Sci.,76 (1): 58-61 (2006).

Joshi P. K., Singh, N.P., Singh, N.N, Gerpacio, R.V. and Pingali, P.L.: Maize in India: production systems, constraints, and research priorities. Mexico, D.F: CIMMYT pp: 1-30 (2005).

Khan, Khalid Saifullah and Joergensen, Rainer Georg: Effects of $\mathrm{Zn}$ and $\mathrm{P}$ addition on the microbial biomass in a $\mathrm{Zn}$ deficient calcareous soil amended with glucose Plant and Soil 335:493499 (2010).

Liang Qiong, Chen Haiqing, Gong Yuanshi, Fan Mingsheng, Yang Hefa, Lal Rattan and Kuzyakov Yakov: Effects of 15 years of manure and inorganic fertilizers on soil organic carbon fractions in a wheat-maize system in the North China Plain Nutr. Cycling in Agroeco., 92: 21-33 (2012).

Lindsay, W.L. and Norvell, W.A.: Development of DTPA soil test for zinc, iron, manganese and copper. Soil Sci. Soc. America J., 42:421-428 (1978).

Misra, B. K., Sharma, Rajiv K. and Nagarajan, S.: Plant breeding: a component of public health strategy Current Sci., 86(9): 1210-1216 (2005).

Olsen, B.C. and Cole, C.V., Watenabe, F.S. and Dean, L.A.: estimation of available phosphorus by extraction with sodium carbonate, USDA Circ. No. 939, pp 19 
(1954).

Osiname, O. A., Kang B. T., Schulte, E. E. and Corey, R. B.: Zinc Response of Maize (Zea mays L.) Grown on Sandy Inceptisols in Western Nigeria Agronomy J., 65: 875-877 (1973).

Patel, Archana B., Manju, Mamta, Badhoniya, Neetu and Kulkarni, H.: What zinc supplementation does and does not achieve in diarrhoea prevention: a systematic review and meta-analysis BMC Infectious Diseases11: 122 (2011).

Piper, C.S.: Soil and plant analysis The University of Adelaide, Australia: 286287 (1950).

Ram, S., Verma, A. and Sharma, S.: Large variability exits in phytase levels among Indian wheat varieties and synthetic hexaploids. J. Cereal Sci., 52: 486-490 (2010).

Sachin, H., Malve, R., and Bhatt, S.: influence of row ratio and zinc levels on productivity, economics, nutrient uptake and soil fertility status of soil on maize (Zea mays) - soybean (Glycine max) intercropping systems under rainfed conditions. www.2011_zinccrops2011_ sachin_abstract.pdf(2011).

Sajedi, N., Ardakani, M., Rejali, F. Mohabbati, F. and Miransari, M.: Yield and yield components of hybrid corn (Zea mays L.) as affected by mycorrhizal symbiosis and zinc sulfate under drought stress Physio. and Mol. Bio.of Plants, 16(4): 343-351 (2010).

Salehin, F. and Rahman, S.: Effects of zinc and nitrogen fertilizer and their application method on yield and yield components of Phaseolus vulgaris L. Agric. Sci., 3: 9-13 (2012).

Shukla, U. C and Prasad, K. G.: ameliorative role of zinc on maize growth under alkali soil condition. Agronomy J., 66:804-806 (1974).

Simic Domagoj, SnežAna Mladenovic
Drinic, Zvonimir Zdunic, Antun Jambrovic, Tatjana Ledenc Josip Brkic, Andrija Brkic, and Ivan, B.: quantitative trait loci for biofortification traits in maize grain $J$ of Heredity, 103(1): 4754 (2012).

Singh, M. V.: Scenario of zinc deficiency in Indian soils and its influence on zinc enrichment in crops for improving human and animal health $w w w .2011 \_z i n c c r o p s 2011 \_m v \_s i n g h \_k$ eynote.pdf(2011).

Singh, R., Sharma, A. R., Dhyani, S. K. and Dubey, R. K.: Tillage and mulching effects on performance of maize (Zea mays)-wheat (Triticum aestivum) cropping system under varying land slopes. Indian J. of Agric. Sci., 81(4): 330-335 (2010).

Singh, N.B., Kumar, V., Singh, G.S., Singh, Y.P., Singh, I.J., Kumar, J., Singh, K.N. and Srivastava, J.K variability in response to zinc application in wheat genotypes. Indian J. of Plant Physio., 14 (4): 413-417(2009).

Subbiah, B.V. and Asija, G. L.: A rapid procedure for the determination of available nitrogen in soils Current Sci., 25: 259-260 (1956).

Suri, I. K., Prasad, R. and Shivay, Y. S.: Zinc oxide-neem oil conditioning for improving the quality of the micronutrient fertilizer zinc sulphate heptahydrate. Current Sci., 100(1):2728 (2011).

Talliee, A. A. and Abedi, M. J.: Study on effect of different amount of zinc application and estimation of critical limit of zinc on dryland wheat (Triticum aestivum) in Kermanshah province Iranian J. of Crop Sci., 1(3):1 (1999).

Paul, T. Sombilla, M. A., Ewing J. Jackson and Escaler Margarita.: Feeding Asia in the 21st century: building urban-rural alliances: summary of the main findings of the international conference on Asian 
food security held in Singapore on 10 12 August 2011. Food Security DOI 10.1007/s12571-011-0159-7(2012).

Verma, T. S. and Minhas, R. S.: Zinc and phosphorus interaction in a wheat-maize cropping system Nutrient Cycling in Agroecosystems 13 (1): 77-86 (1987).
Waters, B. M., Uauy, C., Dubcovsky, J. and Grusak, M. A.: wheat (Triticum aestivum) NAM proteins regulate the translocation of iron, zinc, and nitrogen compounds from vegetative tissues to grain Journal of Expl. Bot., 60 (15): 4263-4274 (2009).

\section{How to cite this article:}

Dileep Kumar, Shiva Dhar, Sanjeev Kumar, Dinesh Chand Meena and Ram Bhawan Meena. 2019. Effect of Zinc Application on Yield Attributes and Yield of Maize and Wheat in MaizeWheat Cropping System. Int.J.Curr.Microbiol.App.Sci. 8(01): 1931-1941. doi: https://doi.org/10.20546/ijcmas.2019.801.203 